\title{
培養されたヒト肺癌細胞の制癌剤に対する 感受性の測定に関する実験的研究
}

\author{
An Experimental Study on Testing the Sensitivity of Cultured \\ Human Lung Cancer Cells to Anti-cancer Drugs.
}

長瀬千秋

抄録：ヒト肺癌細胞を培養し，制癌剂作用下におけるその微小 colony の形成の抑制を指標にし て制癌剤感受性を調べた。その結果, 腫瘍細胞の制癌剂感受性はその増殖速度と関係し, また，組織型と関係なく各々異なり，そして株化や継代中の性格の変化により変わるこ とがわかった。従って, 臨床応用を目的とした制癌剂感受性試験は初代培盖の段階で行 なわれるべきこと，および本試験が臨床的意義を有するであろうことが推察された。

\section{はじめに}

悪性腫瘍の化学療法は過去30余年間に大きな 進歩をとげた。しかし，いまだに悪性腫瘍細胞 のみを障害し，正常細胞を温存するような特効 的な制癌剤は発見されていない。そして, 現存 の制癌剤は正常細胞にも何らかの障害を及ぼす ため，その使用量が制限され，そのために十分 な抗腫瘍効果が得られないことが多い，時には 制癌剂が抗腫瘍効果を示さないばかりか, 副作 用をもたらすのみで，そのためにかえって腫痬 の増大を促進することさえあり得る!

そこでこのような現存の制癌剤の副作用を最 小限にとどめて, 最大限の抗腫瘍効果をもたら そうとする試みが行なわれてきた。その1つは 異なった作用機序を持ついくつかの制癌剤によ る多剂併用療法であり，他の 1 つは個々の悪性 腫瘍の制癌剂に対する感受性をあらかじめ検査 することによる選択的化学療法である. 前者に 関しては現在に至るまでに数多くの実験的, 臨

天理よろず相談所病院胸部外科
床的報告があり，肺癌においても有効率の上昇 が得られている. 2) 後者に関しても過去に種々の 方法が報告されているが, ${ }^{3)}$ その臨床的応用はい まだ日常化していない.

選択的化学療法においては, 無効と判定され た制癌剤の投与を控えて, 不必要な副作用を避 けることができ，また，有効と判定された制癌 剂の場合には，ある程度の副作用を犠性にして でも，予想される抗腫瘍効果をより重視して， 強力な化学療法を行なうことができるという利 点がある。

悪性腫瘍の制癌剤に対する感受性を in vitro で調べる方法, すなわち制癌剂感受性試験法に は大別して間接的方法と直接的方法がある。前 者は制癌剂作用後の腫癔細胞の生死を何らかの indicator（色素染色性，酵素活性，），6）isotope で labelされた核酸や蛋白質の前駆物質の細胞内へ

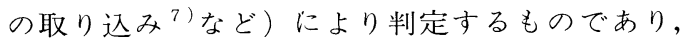
後者はそれに対して, 腫瘍細胞の生死を組織培 養下での colony 数 ${ }^{8)}$ や生細胞数 ${ }^{9), 10)}$ の算定, あ

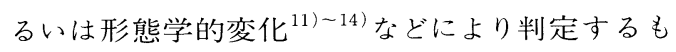


Table 1. Anticancer drugs

\begin{tabular}{l|l|l|l} 
Drugs & Presumed action & Trade name & Supplier \\
\hline 5-fluorouracil & anti-metabolite & 5-FU-Kyowa & Kyowa Hakko \\
arabinosylcytosine & anti-metabolite & Cylocide & Nihon Shinyaku \\
amethopterin & anti-metabolite & Methotrexate & Takeda \\
ifosphamide & alkylating & & Shionogi \\
nitrogen mustard & & & \\
N-oxide & alkylating & Nitromin & Takeda \\
carbazilquinone & alkylating & Esquinone & Sankyo \\
vincristine & anti-mitotic & Oncovin & Shionogi \\
bleomycin & antibiotic & Bleo & Nihon Kayaku \\
mitomycin C & antibiotic & Mitomycin-Kyowa-S & Kyowa Hakko \\
chromomycin A3 & antibiotic & Toyomycin & Takeda \\
adriamycin & antibiotic & Adriacin & Kyowa \\
actinomycin D & antibiotic & Lyovac-Cosmegen & Nihon Merck Banyu \\
& & &
\end{tabular}

のである。各方法にはそれぞれ長所と短所があ ク，いまだに最良の制癌剂感受性試験法という べきものは確立されていないのが現状である。 最近ではisotope取り込みを利用する間接法の報 告が多いが，組織培養による直接法も今なお報 告されている.

著者は組織培養法の意義と問題点を検討する ため，樹立継代されたいくつかの人肺癌細胞株 （縦隔腫瘍細胞株も含む。）および初代培養の段 階の種々の人肺癌細胞を用いて, 組織培養下で の腫瘍細胞の微小 colony 形成能 (場合により生 着細胞数）を指標にした制癌剂感受性試験を試 みた。著者の方法が今までの組織培養法の報告 と異なる点は, 簡便性を重視して, 培養容器に microplateを応用したことである.以下に著者の 方法の概要とそれにより得られた結果を報告し， その意義と問題点について検討を加える.

\section{材科および方法}

\section{1.薬品および器具}

1)制癌剤：表 1 に示す 12 種類の薬剤について 検査した。

2)培養液 : 20\%のFetal Calf Serum(GIBCO) で補われたRPMI-1640 (日水製薬)にPenicillinStreptomycin Solution(GIBCO)をそれぞれ100u./ $\mathrm{ml}, 100 \mu \mathrm{g} / \mathrm{ml}$ の濃度となるように加えた。

3 ) 培養容器: Falcon"MicroTest II" (Becton, Dickinson Overseas Inc.) を使用した。

\section{2.腫瘍細胞}

1)細胞株 : 人肺癌および縦隔腫瘍から著者に より樹立されたLK-14 (肺大細胞癌由来), LK-15 (肺腺癌由来), LK-15(tr-1) (LK-15の変異株). MRS-1（縦隔細網肉腫由来）と, 島根医大病理 森川教授より提供を受けた HPL-GCC-1（肺巨 細胞癌由来) HPL-GCC-2（同）HLT-OAT-3(肺 小細胞癌由来）の 7 株について検討した。なお, 比較のために， mouseの腫瘍から著者により樹 立されたL-1210/tc (BDF 1 mouseで縦代された L-1210白血病由来) と EA (Ehrlich腹水癌由来) に ついての検討も付け加之た。

2)初代培養腫瘍細胞：京大胸部研胸部外科, 関西医大胸部外科および天理よろず相談所病院 胸部外科において, 手術により得られた肺癌 (縦 隔その他の悪性腫瘍も含む.) 33症例について検 討した。その内訳は表 6 に示す通りである。

\section{3. 検査方法}

1)制癌剤の稀釈：二通りの方法で行なった。 その一つは小試験管内で各制癌剤について10倍 稀釈で 5 〜 段階の濃度勾配を作り，それぞれ をmicroplate (Falcon "MicroTest II") のwellに $0.1 \mathrm{ml}$ ずつ移す方法である。他方は各制癌剂に ついて microplateの wellの中でTitertek "Multidiluter" (Flow Labolatories)により，5倍稀釈 で 7 〜 15段階の濃度勾配を作る方法である．前 者は各細胞株および1977年以前の23例の初代培 養細胞について行ない，後者は1978年以降の 10 
Fig. 1. Discontinuous density gradients.

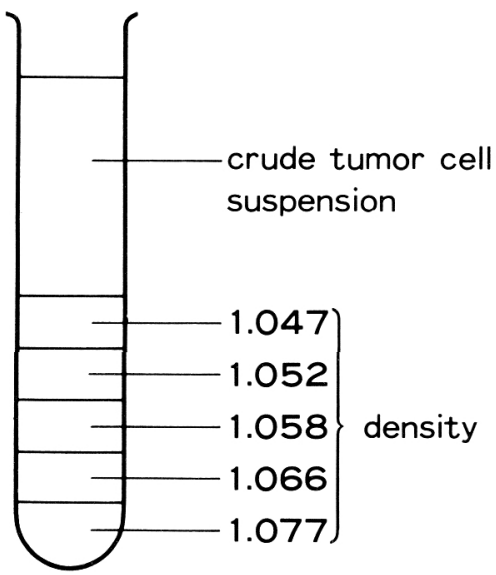

例の初代培養細胞について行なった。いずれも 最高濃度は各制癌剂の in vitroに戈ける増殖阻 止効果の強さによって経験的に決めた。なお， 粉末薬剂甠理食塩水で溶解させ，稀釈はす心゙ て培養液で行なった。

2)腫揞細胞浮遊液の作成: 細胞株の場合, LK 14, LK-15(tr-1) の 2 株はtrypsin処理で，他は すべて pipettingで細胞を集め， 2 - $3 \times 10^{3} / \mathrm{ml}$ の細胞浮遊液を作った。初代培養細胞の場合は 次の方法によった。まず，手術などで得られた 腫瘍組織から壊死の少ない部分を約 $1 \mathrm{~cm}^{3}$ 以上 切り出し，培養液の入った dishの中で歯科用ピ ンセットと使い捨て用の尖刃刀で $1 \mathrm{~mm}^{3}$ 以下の 小片に細切した。次にこれを小試験管に入れて pipettingにより数分間器械的に攪挥し，小片か ら単離腫瘍細胞やclump を遊離させた。そして 小片沈澱後の supernatantを吸引して, crudeな 腫瘍細胞浮遊液を小片から分離し，遠沈に上る 洗浄を2回行なって培養液に浮遊させた。1977 年以前の段階ではこれを用いて検查したが，赤 血球, 白血球, 非腫瘍性細胞, 死滅腫瘍細胞あ るいは微細顕粘状破片などが顕微境観察の妨げ になることを考慮して，1978年以降の10症例で は, 図 1 に示古不連続密度勾配 (Sykesの方法 ${ }^{15)}$ に準じて作成した。)によってそれらを除いた。 すなわち，この不連続密度勾配の上に腫湯細胞 浮遊液を重層し，1,500r.p.m.で10分閒遠沈して， いずれかの interface（密度層間）に集まる腫瘍
Fig. 2. An example of a microcolony of primarily cultured tumor cells (Phase contrast, X 100)

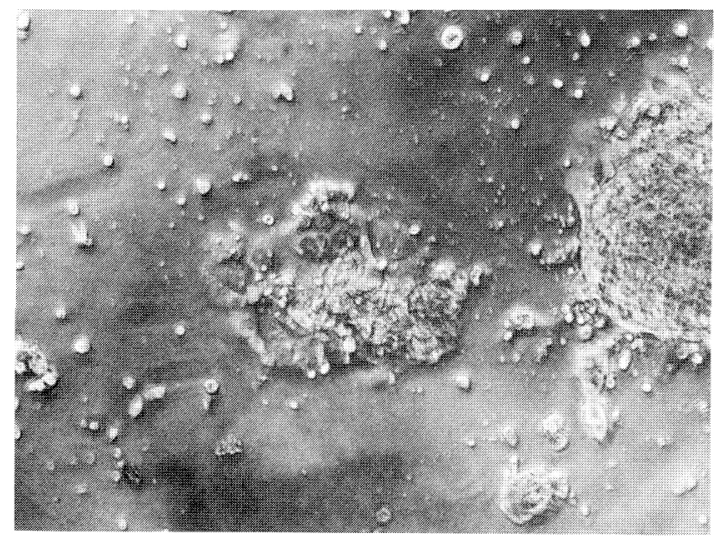

細胞を採集し，遠沈による洗浄を 2 回行なって， 培養液に浮遊させ，これ老腫湯細胞浮遊液とし た。

3)腫瘍細胞の制癌剂に対する感受性の検相： 稀釈された制癌剤の入った microplateの各 well に腫瘍細胞浮遊液圭 $0.1 \mathrm{ml}$ ずつ分注して, 炭酸 ガス培養器 (TOKIWA, CO-2) の中で $5 \% \mathrm{CO}^{2}$, $95 \%$ air $37^{\circ} \mathrm{C}$, 湿度 $100 \%$ 環境のもとに, 腫瘍 細胞を種々の濃度の各種制癌剂とともに培養し た。一定時間 $(72 \sim 216$ 時間：腫瘍細胞の増殖速 度によって異なる。）後に microplateの wellから 培養液を吸引して制癌剂を除き，新たに培養液 〔浮遊型腫癔細胞の場合は0.3\%のSpecial Agar Noble (DIFCO) を含む.」をO. $2 \mathrm{ml}$ ずつ分注して さらに培盖を続けた。そして腫隍細胞が増殖し て，8〜16個の細胞からなる微小colonyとなる 時期に, microplate の well の底面を倒立位相差 顕微鏡で観察した。制癌剂の入っていた wellの 中の腫瘍細胞の徵小colonyの数が対照の wellの それに比べて10\%以下であれば，その制癌㓮が その濃度で有効と判定し, 有効な最小濃度を各 制癌剂について調べた。徽小colonyを作らない 腫晹細胞の場合は, weIlの底に生着している腫 瘍細胞を数之ることによって同様の $90 \%$ 増殖阻 止最小濃度を調べた。初代培養に扔いて，徽小 colonyあるいは生着細胞が腫瘍細胞由来である か否かの判別は，Cobb弓 ${ }^{16)}$ の基準に従い，悪性 腫晹細胞の組織培善下での形態学的特徵を参考 
Fig. 3. Phase contrast photomicrograph of LK-14 cells that originated from a large cell carcinoma of the lung (X 100)

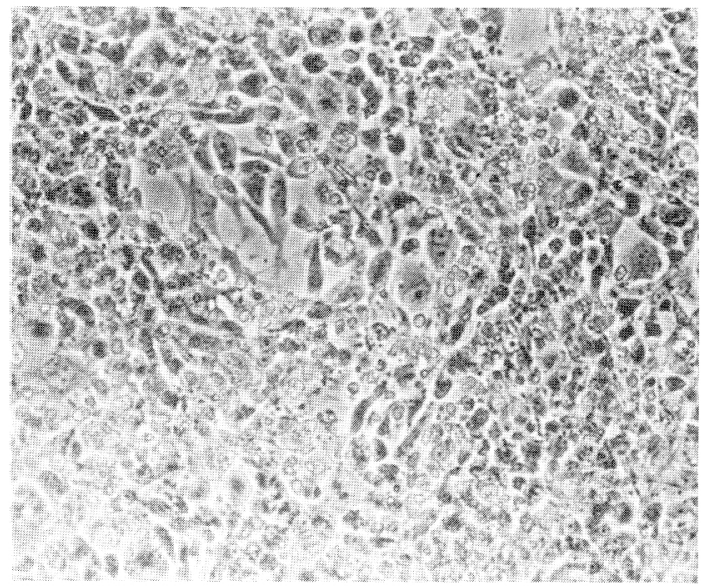

Fig. 4. Phase contrast photomicrograph of MRS- 1 cells that originated from a mediastinal reticulosarcoma $(\mathrm{X} 100)$

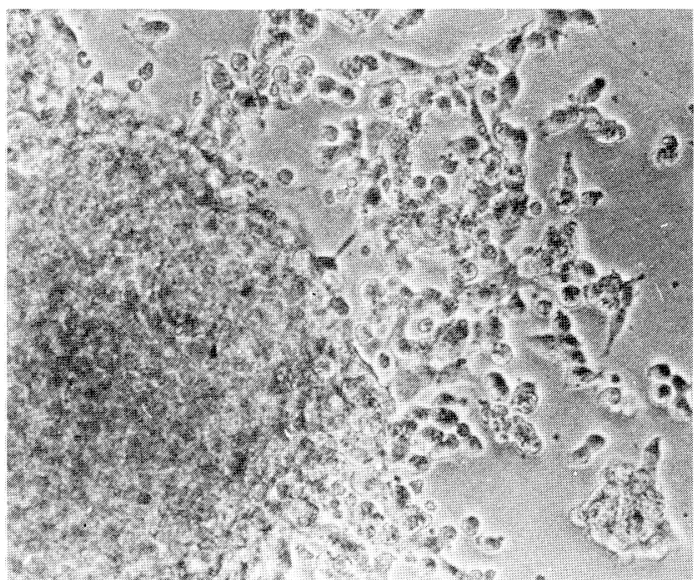

Table 2. Minimum 90\% inhibitory concentration of drugs to L-1210/tc, LK-14, MRS-1 and HLT-OAT-3 $(\mu \mathrm{g} / \mathrm{m} \ell)$

\begin{tabular}{|c|c|c|c|c|}
\hline & $\mathrm{L}-1210 / \mathrm{tc}$ & LK-14 & MRS-1 & HLT-OAT-3 \\
\hline 5-fluorouracil & 1 & 100 & $>10$ & $>100$ \\
\hline arabinosylcytosine & $1 \times 10^{-3}$ & 10 & $>1$ & $>10$ \\
\hline amethopterin & & $<1 \times 10^{-4}$ & & $>10$ \\
\hline carbazilquinone & $1 \times 10^{-2}$ & $1 \times 10^{-2}$ & $1 \times 10^{-2}$ & $1 \times 10^{-1}$ \\
\hline vincristine & $1 \times 10^{-3}$ & $1 \times 10^{-1}$ & $1 \times 10^{-1}$ & $>10$ \\
\hline bleomycin & 10 & & 1 & \\
\hline mitomycin $\mathrm{C}$ & $1 \times 10^{-1}$ & 1 & 1 & 10 \\
\hline chromomycin $\mathrm{A}_{3}$ & $1 \times 10^{-3}$ & $<1 \times 10^{-4}$ & $<1 \times 10^{-6}$ & $>1 \times 10^{-2}$ \\
\hline adriamycin & $1 \times 10^{-4}$ & $1 \times 10^{-1}$ & & 10 \\
\hline actinomycin D & $<1 \times 10^{-7}$ & $<1 \times 10^{-4}$ & & $>0$ \\
\hline incubation with drugs & 98 hrs. & $72 \mathrm{hrs}$ & $72 \mathrm{hrs}$. & $72 \mathrm{hrs}$. \\
\hline doubling time & ca. $1 / 2$ day & ca. 1 day & ca. 5 days & ca. 7 days \\
\hline
\end{tabular}

にしたが，明確でない場合はGiemsa染色とPapanicolaou染色を行なって悪性であることを確 かめた。図 2 は初代培養での悪性腫演細胞由来 の微小colonyの1例である。

\section{結 果}

।.細胞株の制癌剤に対する感受性の測定

1)細胞株の制癌剂感受性とその増殖速度との 関係：図 3，図4 はそれぞれLK-14, MRS-1の 細胞の位相差顕微鏡写真である。LK-14の腫瘍 性はnude mouse への移殖による生着と組織像 から確かめられた。 MRS-1の腫瘍性は培盖細胞
の電顕像から確か女られた。表 2 にL-1210/tc, LK-14, MRS-1, HLT-OAT-3の制癌剂感受性を 90\%增殖阻止最小濃度で比較した。その結果, 一般に增殖の遅い細胞株ほど制癌剂感受性も低 いことが確かめられた。しかし，この原則があ てはまらない場合(例之ばMRS-1に対するchroー momycin $\mathrm{A}_{3}$ ) 毛認女られた。

$2)$ 同組織型由来の 2 細胞株の制癌剂感受性の 比較：同組織型由来で増殖速度もほぼ同じであ る HPL-GCC-1 と HPL-GCC-2の別々の症例から 樹立された 2 細胞株に対する各種制癌剂の $90 \%$ 增殖阻止最小濃度を表 3 に示した。両者の制癌 
Table 3. Minimum 90\% inhibitory concentration of drugs to HPL-GCC- 1 and HPL-GCC- $2(\mu \mathrm{g} / \mathrm{m} \ell)$

\begin{tabular}{l|c|c} 
& HPL-GCC-1 & HPL-GCC-2 \\
\hline 5-fluorouracil & 100 & $>100$ \\
arabinosylcytosine & $>10$ & $>10$ \\
amethopterin & $>10$ & $>10$ \\
carbazilquinone & $1 \times 10^{-2}$ & $1 \times 10^{-2}$ \\
vincristine & $>10$ & $1 \times 10^{-1}$ \\
mitomycin C & 1 & 1 \\
chromomycin $\mathrm{A}_{3}$ & $1 \times 10^{-6}$ & $1 \times 10^{-3}$ \\
adriamycin & $1 \times 10^{-1}$ & $>10$ \\
actionmycin D & $<1 \times 10^{-4}$ & $<1 \times 10^{-4}$ \\
\hline incubation with & 72 hrs. & 72 hrs. \\
drugs & & ca. 2 days
\end{tabular}

Table 4. Minimum 90\% inhibitory concentration of drugs to LK-15 and LK-15 (tr- 1$)(\mu \mathrm{g} / \mathrm{m} \ell)$

\begin{tabular}{|c|c|c|}
\hline & LK-15 & LK-15 (tr-1) \\
\hline 5-fluorouracil & $>100$ & $<1 \times 10^{-2}$ \\
\hline arabinosylcy tosine & $>10$ & $<1 \times 10^{-3}$ \\
\hline carbazilquinone & $1 \times 10^{-1}$ & $<1 \times 10^{-4}$ \\
\hline vincristine & $>10$ & $<1 \times 10^{-3}$ \\
\hline bleomycin & 10 & $1 \times 10^{-1}$ \\
\hline mitomycin $\mathrm{C}$ & 10 & $<1 \times 10^{-3}$ \\
\hline adriamycin & 1 & $<1 \times 10^{-3}$ \\
\hline actinomycin D & $1 \times 10^{-3}$ & $<1 \times 10^{-6}$ \\
\hline incubation with drugs & $72 \mathrm{hrs}$. & 85 hrs. \\
\hline doubling time & ca. 4 days & ca. 2 days \\
\hline
\end{tabular}

Table 5. Minimum $90 \%$ inhibitory concentration of drugs to Ehrlich ascites carcinoma cells $(\mu \mathrm{g} / \mathrm{m} \ell)$

\begin{tabular}{l|c|c} 
& $\begin{array}{c}\text { primarily } \\
\text { cultured cells }\end{array}$ & $\begin{array}{c}\text { EA (after } \\
\text { establishment) }\end{array}$ \\
\hline $\begin{array}{l}\text { 5-fluorouracil } \\
\text { arabinosylcy tosine }\end{array}$ & 1 & $>1 \times 10^{-1}$ \\
$\begin{array}{l}\text { carbazilquinone } \\
\text { bleomycin }\end{array}$ & $1 \times 10^{-4}$ & $1 \times 10^{-4}$ \\
mitomycin C & 10 & $1 \times 10^{-4}$ \\
\hline $\begin{array}{l}\text { incubation with } \\
\text { drugs }\end{array}$ & $216 \mathrm{hrs.}$ & $1 \times 10^{-2}$ \\
\hline
\end{tabular}

剤感受性はよく似ていたが, chromomycin $\mathrm{A}_{3}$, adriamycin およびvincristine に対する感受性は 異なっていた。

3)株化，または樹立後継代中の細胞株の性格 の変化による制癌剂感受性の変化：罒 5, 図6 はLK-15とそれが樹立後 4 个月目に性格が変化
Fig. 5. Phase contrast photomicrograph of LK15 cells that originated from an adenocarcinoma of the lung (X 100)

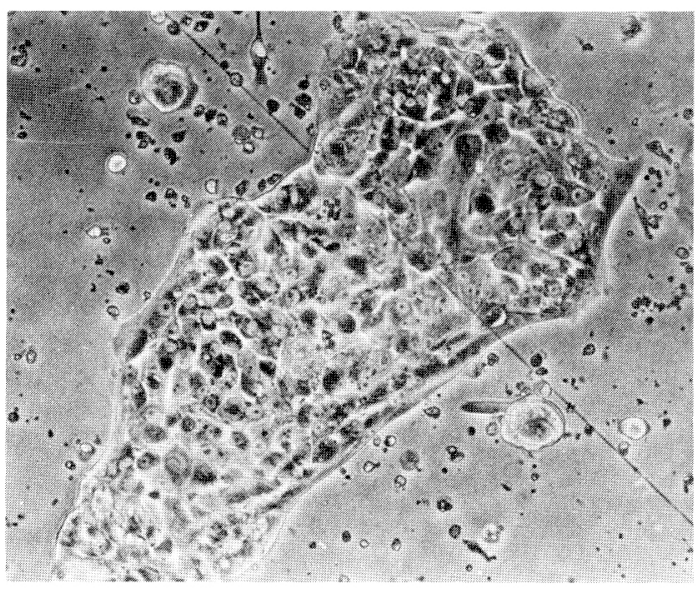

Fig. 6. Phase contrast photomicrograph of LK15 (tr-1) cells that originated from LK15 cells with the change of their character four months after the establishment of that cell line (X 100)

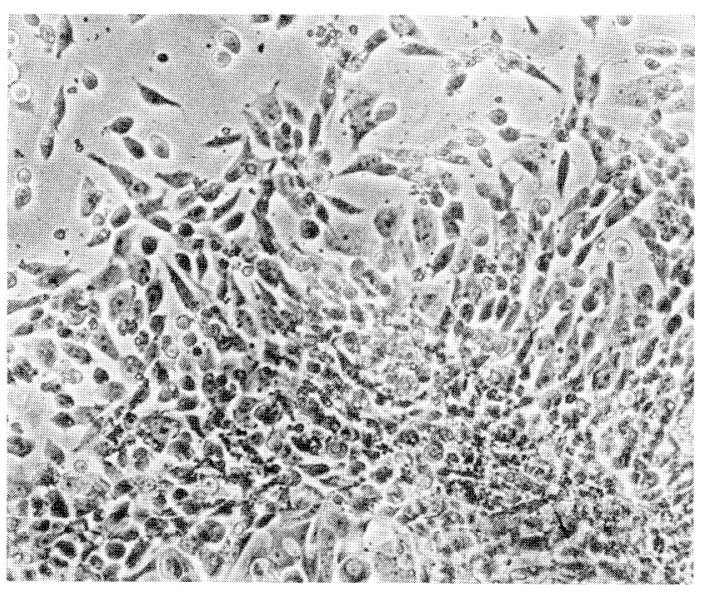

して生じた LK-15(tr-1) の細胞の位相差顕微鏡 写真である。表 4 にそれらの株細胞の制癌剂感 受性を各制癌剂の $90 \%$ 増殖阻止最小濃度で示し た。この表からわかるように, 変異によって多くの 制癌剂に対する感受性が高まることが確かめら れた。そしてこの制癌剂感受性の艺進は，性格 の変化により生じた倍加時間の短縮で説明され 得る以上のものであった。表 5 はEA株 (Ehrlich 腹水癌由来）の株化前後の制癌剂感受性である がややはり株化によって制癌剂感受性が高まる ことが認められた。 
2. 初代培養腫瘍細胞の制癌剤に対する感受性 の測定

1)初代培養での制癌剂感受性試験の成功率： 表 6 に示す各腫瘍について検査したが，検査に 成功したのは33例中15例であった。不成功例は 初期の段階でのものが多く，その原因は腫瘍細 胞以外の種々の夾雑物が腫痬細胞の微小 colony を顕微鏡で観察する上で妨げになることであっ た。不連続密度勾配によりそのような夾雑物を 除いた1978年以降の症例では70\%(10例中 7 例) の成功率を得ており，これは本法適用前の成功 率35\%（23例中 8 例）に比べて有意に高い。本 法適用後の 3 例での不成功の原因は, 腫瘍組織 中に in vitro で増殖し得る生きた腫瘍細胞が少 ないか, あるいは腫瘍が硬いため, 器械的方法
Table 6. Cases tested at primary culture

\begin{tabular}{l|c|c}
\multicolumn{1}{c|}{ Tumors } & Cases tried & $\begin{array}{c}\text { Cases of } \\
\text { success }\end{array}$ \\
\hline $\begin{array}{l}\text { primary lung cancer } \\
\text { osteosarcoma } \\
\text { (pulmonary metastases) }\end{array}$ & 21 & 7 \\
$\begin{array}{l}\text { gastric cancer } \\
\text { (supraclavicular metastases) }\end{array}$ & 1 & 3 \\
$\begin{array}{l}\text { malignant thymoma } \\
\text { breast cancer }\end{array}$ & 1 & 1 \\
$\begin{array}{l}\text { (pulmonary metastases) } \\
\text { chest wall cancer }\end{array}$ & 1 & 1 \\
$\begin{array}{l}\text { cervical cancer } \\
\text { (pulmonary metastases) } \\
\text { skin cancer }\end{array}$ & 1 & 1 \\
$\begin{array}{l}\text { (subaxillar metastasis) } \\
\text { melanoma } \\
\text { (pulmonary metastases) }\end{array}$ & 1 & 0 \\
\hline \multicolumn{1}{c|}{ total } & 33 & $15(45 \%)$
\end{tabular}

Table 7. Minimum $90 \%$ inhibitory concentration of drugs to primarily cultured lung cancer cells $(\mu \mathrm{g} / \mathrm{m} \ell)$

\begin{tabular}{|c|c|c|c|c|c|c|c|}
\hline & $\begin{array}{c}\text { LK-25 } \\
\text { (adeno ca.) }\end{array}$ & $\begin{array}{c}\text { LK-52 } \\
\text { (adeno ca.) }\end{array}$ & $\begin{array}{c}\text { HLC-A } \\
\text { (adeno ca.) }\end{array}$ & $\begin{array}{c}\text { LK-38 } \\
\text { (sq. cell ca.) }\end{array}$ & $\begin{array}{l}\text { HPC-2 } \\
\text { (small cell } \\
\text { ca.) }\end{array}$ & $\begin{array}{l}\text { HPC-4 } \\
\text { (small cell } \\
\text { ca.) }\end{array}$ & $\begin{array}{c}\text { HPC-3 } \\
\text { giant cell } \\
\text { ca.) }\end{array}$ \\
\hline 5-fluorouracil & 100 & 1 & 10 & 10 & $>10$ & 20 & 20 \\
\hline arabinosylcy tosine & $>10$ & $>1$ & $>1$ & 1 & $>1$ & 20 & 100 \\
\hline amethopterin & $>10$ & & & & $>10$ & 100 & 20 \\
\hline ifosphamide & & $>10$ & $>10$ & & & $>100$ & 20 \\
\hline carbazilquinone & $1 \times 10^{-1}$ & $1 \times 10^{-1}$ & $1 \times 10^{-2}$ & $1 \times 10^{-2}$ & $1 \times 10^{-2}$ & $3 \times 10^{-2}$ & $2 \times 10^{-6}$ \\
\hline vincristine & 10 & $1 \times 10^{-1}$ & & 1 & $>1$ & $8 \times 10^{-1}$ & 20 \\
\hline bleomycin & & $1 \times 10^{-1}$ & $>10$ & 1 & $>10$ & 20 & \\
\hline mitomy $\operatorname{cin} \mathrm{C}$ & $>10$ & $1 \times 10^{-1}$ & $1 \times 10^{-1}$ & $1 \times 10^{-1}$ & $>1$ & 20 & 20 \\
\hline chromomycin $\mathbf{A}_{\mathbf{3}}$ & $1 \times 10^{-3}$ & $1 \times 10^{-2}$ & & $1 \times 10^{-4}$ & $1 \times 10^{-2}$ & $2 \times 10^{-6}$ & $1 \times 10^{-5}$ \\
\hline adriamycin & 10 & & & & & 4 & 4 \\
\hline actinomycin D & $>10$ & $<1 \times 10^{-7}$ & & $1 \times 10^{-3}$ & & $<1 \times 10^{-7}$ & $2 \times 10^{-6}$ \\
\hline incubation with drugs & 72 hrs. & 144 hrs. & 216 hrs. & 72 hrs. & 120 hrs. & 192 hrs. & 120 hrs. \\
\hline
\end{tabular}

では十分な単離腫瘍細胞が得られないことであ った。

2)初代培養腫瘍細胞の制癌剤に対する感受性 : 表 7 は原発性肺癌 7 症例での制癌剂感受性で ある、表でわかるように, 名症例での各制癌剤の $90 \%$ 増殖阻止最小濃度には相当の差のあること が確かめられた。また, 骨肉腫の肺転移例 3 症例 の制癌剂感受性は表 8 のおりであるが, この 場合も各症例での制癌剤感受性は異なっていた。 他の 5 症例（胃癌肺転移例，子宮癌肺転移例, 乳癌肺転移例, 悪性胸腺腫, 胸壁扁平上皮癌）に ついても，表 9 の如くで結果は同様であった。
表 9 の中で，きわめて増殖の速い悪性胸腺腫の 制癌剂感受性が, きわめて増殖の遅い乳癌のそ れに比べてはるかに高いことが注目された。

\section{考 察}

\section{1. 実験方法に関する検討}

著者の方法は組織培養下での腫瘍細胞の微小 colonyの数または生着細胞数を判定基準にして いるため，その判定に主観が入ることが大きな 問題点である。それによる問題の 1 つは，初代 培養の場合における腫瘍細胞の同定に関してで あり，他の 1 つは腫痬細胞の生死の判定に関し 
Table 8. Minimum $90 \%$ inhibitory concentration of drugs to primarily cultured osteogenic osteosarcoma cells $(\mu \mathrm{g} / \mathrm{m} \ell)$

\begin{tabular}{l|c|c|c} 
& OS- 1 & OS-3 & OS-4 \\
\hline $\begin{array}{l}\text { 5-fluorouracil } \\
\text { arabinosylcytosine }\end{array}$ & 10 & $>10$ & $>10$ \\
carbazilquinone & 1 & $>1 \times 10^{-1}$ & $>1$ \\
vincristine & $1 \times 10^{-3}$ & $>1 \times 10^{-1}$ & $1 \times 10^{-2}$ \\
bleomycin & $>1$ & $1 \times 10^{-1}$ & 1 \\
mitomycin C & $1 \times 10^{-2}$ & $>1 \times 10^{-3}$ & 1 \\
chromomycin A & $1 \times 10^{-3}$ & $1 \times 10^{-1}$ & $<1 \times 10^{-6}$ \\
adriamycin & $1 \times 10^{-6}$ & $1 \times 10^{-7}$ & $<1 \times 10^{-3}$ \\
actinomycin D & $69 \mathrm{hrs}$. & $96 \mathrm{hrs}$. & $96 \mathrm{hrs}$.
\end{tabular}

Table 9. Minimum $90 \%$ inhibitory concentration of drugs to various tumor cells $(\mu \mathrm{g} / \mathrm{m} \ell)$

\begin{tabular}{|c|c|c|c|c|c|}
\hline & $\begin{array}{l}\text { WADA } \\
\text { gastric cancer } \\
\text { undiff. cell ca. }\end{array}$ & $\begin{array}{c}\text { THY-2 } \\
\text { malignant thymoma } \\
\text { (epithelial type) }\end{array}$ & $\begin{array}{c}\text { MK-1 } \\
\text { breast cancer } \\
\text { (adeno ca.) }\end{array}$ & $\begin{array}{c}\text { CWT } \\
\text { chest wall cancer } \\
\text { (sq. cell ca.) }\end{array}$ & $\begin{array}{c}\text { CC-1 } \\
\text { cervical cancer } \\
\text { (sq. cell ca.) }\end{array}$ \\
\hline $\begin{array}{l}\text { 5-fluorouracil } \\
\text { arabinosylcytosine } \\
\text { amethopterin } \\
\text { carbazilquinone } \\
\text { vincristine } \\
\text { bleomycin } \\
\text { mitomycin C } \\
\text { chromomycin } \mathrm{A}_{3} \\
\text { adriamycin } \\
\text { actinomycin D }\end{array}$ & $\begin{array}{c}>1 \\
>10 \\
1 \times 10^{-2} \\
1 \times 10^{-2} \\
1 \\
1 \\
1 \times 10^{-4} \\
1\end{array}$ & $\begin{array}{r}1 \times 10^{-4} \\
1 \times 10^{-1} \\
1 \times 10^{-3} \\
\\
1 \times 10^{-2} \\
<1 \times 10^{-6}\end{array}$ & $\begin{array}{c}>100 \\
>10 \\
>1 \\
>10 \\
>10 \\
10 \\
>1 \times 10^{-2} \\
>1 \times 10^{-2}\end{array}$ & $\begin{array}{c}1 \\
1 \times 10^{-1} \\
1 \times 10^{-1} \\
1 \\
1 \times 10^{-2} \\
1 \times 10^{-1} \\
1 \times 10^{-2} \\
<1 \times 10^{-9}\end{array}$ & $\begin{array}{c}20 \\
20 \\
100 \\
2 \\
20 \\
20 \\
4 \\
2 \times 10^{-6} \\
4 \\
<6 \times 10^{-9}\end{array}$ \\
\hline incubation with drugs & $67 \mathrm{hrs}$. & 69 hrs. & 24 days & $72 \mathrm{hrs}$. & 9 days \\
\hline
\end{tabular}

てである.前者については, 著者はCobbの判定 基準が示すような組織培養下での細胞の形態に より，腫瘍細胞の同定を行ない，殆んどの症例 で困難はなかった。しかし正確を期すためには, 疑わしい場合のみでなく, 全症例でPapanicolaou 染色あるいは染色体数の測定を行なって固定す

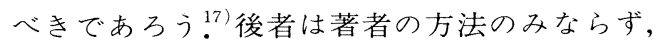
従来の多くの組織培養法に必然的に伴う問題で ある。この問題の解決のためには肉眼的な colony を形成させる方法 ${ }^{8)}$ を用いるとよいが，これは 方法が繁雑であること, 初代培養での成功率が 低いことなどの点であまり実用的でない，著者 の方法は肉眼的な colonyの代わりに微小colony を用いているため, 細胞の生死の判別について, reproductive death などの問題を残しているが, 簡便であること, 成功率の良いこと, 少量の腫 瘍組織で可能であることなどから，ょり実用的 であると言える。

従来の組織培養法による制癌剤感受性試験の 多くは, monolayer culture, explant culture $の$ いずれの場合も，一度細胞を増殖させて後に制 癌剂をを作用させ，その障害の程度を形態学的に 判定しているが; 著者は培養の開始の時から制 癌剤を作用させ, その存在下での腫湯細胞の増 殖の有無を見ており，この点が従来の方法と大 きく異なる。従来の方法では制癌剂の腫瘍細胞 に対する細胞障害性が把握されるのみであるが, 著者の方法では制癌剂の腫瘍細胞に対する増殖 
阻止効果をその種々の濃度で知ることができる。 microplate を制癌剂感受性試験に応用する試 みはすでに $2 ， 3$ 報告があるが，その制癌効果の 判定方法は著者の場合と異なり, Coulter Counterにより生細胞数を算定するもの, ${ }^{18}$ 腫瘍細胞の 酵素活性を利用するもの, ${ }^{19)}$ isotope でlabelされ た蛋白質または核酸の前駆物質の細胞内への取 ク込みによるもの ${ }^{20), 21)}$ などである。どの判定方 法が最善であるかは別として, microplate は少 ない材料で一度に多くの制癌剤についてその種 種の濃度で検査できる利点を持ち, 非常に実用 的である。

\section{2.実験結果についての考察}

腫瘍細胞の制癌剂感受性とその増殖速度との 関連性はいまだ報告がないが，一定の薬剤接触 時間に通過する cell cycle が增殖速度によって 異なることから容易に解釈できる。この現象は 細胞株でも初代培養細胞でも認められ，一般的 に通用する原則であると言えよう。

同臓器癌で同組織型由来の細胞株が制癌剂感 受性を異にすることは Martorelli2, ${ }^{22)}$ Barranco ${ }^{23)}$ 辻 ${ }^{24)}$ らにっって見出されているが，この実験に よってもそれが確かめられた。感受性の差をも たらす原因はいまだに十分解明されていない。 株化や長期継代によって最初の性格が変化する ことも原因の 1 つとして考えられるが，しかし， 初代培養においても, 同じ組織型の同臟器癌(肺 癌, 骨肉腫)が異なった制癌剂感受性を示した。 このことから，個々の腫瘍は各々特有の制癌剂 感受性を持つということができよう。また，こ の結果はこれまでの多くの報告と一致しており， 制癌剂感受性試験が臨床的に有意義であろうこ とを暗示している。

腫瘍細胞の株化あるいは長期継代中の性格の 変化により制癌剂感受性が変わるのは，扔そら く, in vitroで継代を続ける間に, 腫瘍細胞のj ちのあるものだけが選択的に増殖し，もとの腫 瘍細胞集団の性格が失われるためであろう. $\mathrm{Be}$ rryは初代培養においてさえも2 回継代するだけ で制癌剂感受性が変化したことを報告している! これらのことから，臨床応用を目的とした制癌 剂感受性試験は初代培養の早期の段階で行なう
べきであると言える。

\section{3. 今後の問題}

腫瘍細胞の in vitro での制癌剤感受性がその in vivoでの感受性をどの程度正確に反映するか は制癌剤感受性試験における最も重要な問題で ある。この問題の検討のためには多くの臨床応 用例での結果を分析することが必要である。過 去の報告では, 組織培養法でのin vitro と in vivo の相関は60\%以上であった.10),11),13) また，選択的 化学療法と無選択的化学療法との間で, 予後に 有意の差が認められた 25) しかし, Balconiらは動 物癌で in vitro と in vivoの相関が見られなかっ たことを報告し，その原因はin vitroで有効な薬 凨濃度がin vivoで得られないためであることを 明らかにしている ${ }^{26)}$ in vitro とin vivoの相関を 高くするためには, in vitroで作用させる制癌剂 の濃度と接触時間をin vivoでのそれらに近いも のにすることが必要であろう。制癌剤の検查濃 度に関しては, 今までの報告では大体 in vivoで 予想される濃度に合わせているが，著者は基礎 的実験として, 各制癌剂のin vitroでの最小有効 濃度を参考にして, 高濃度より低濃度まで多く の濃度勾配で検査を行なった。従って，この結 果からは臨床効果に関して絶対的な予測はでき ず，各制癌剤について，各症例間での比較的な 臨床効果の予測ができるに過ぎない，将来の臨 床応用のためには，現在までのデー夕を参考に しつつ, 臨床で予想される濃度も考慮して、適 切な濃度範囲で検查を行なう必要がある。

制癌剂の作用時間に関しては，臨床で予想さ れる血中持続時間を考慮して, 短時間接触で検 查を行なっている報告が多い。著者は，多くの 腫瘍細胞が 2 倍に増殖するのに $2 ， 3$ 日以上を 要するので, cell cycleのすべてのphaseで薬剤 が作用するように，制癌剤の接触時間を 72 時間 以上にした。しかし，このような長時間の接触 は臨床では経口投与を除いてあり得ないので, 多くの薬剤は短時間接触で検查を行なうのが適 切であろう。ただし，時間依存性薬郕27)で臨床 でも経口投与が行なわれて長時間の血中有効濃 度が期待できるもの（5-FUなど）は時間的因子 も考慮に入れて検查を行なうべきであろう。 
制癌剤感受性試験が将来臨床において日常的 検查として行なわれるようになるためにはそそ れが簡便かつ正確でなければならない，著者の 方法はこの必要条件を十分に満たすものとは言 えないが，簡便な方法の 1 つとして有意義であ ると思われる.本法の正確度についてはL-1210/ tcでの基礎実験があるが28) 今後さらに人癌細胞 で本法をisotope取り込みによる方法やcolony形 成による方法と比較することが必要である。ま た，本法の臨床的意義を明らかにするには，本 法による選択的化学療法を多くの症例で試み, 腫瘍縮小効果，延命効果などを検討しなければ ならない, 本法の臨床的意義, 他の方法との比 較に関しては後日報告する。

\section{結 論}

人肺癌および縦隔腫瘍由来の 7 細胞株と 33 症 例の初代培養腫瘍細胞の各種制癌剂に対する感 受性を, 組織培養下での腫瘍細胞の微小colony の数または生着細胞数を指標にして比較検討し た。その結果, 以下のことが明らかとなった。

(1)腫瘍細胞の制癌剂感受性には一般的にその 増殖速度が関係し, 増殖の遅い腫瘍細胞は制癌 剂感受性も低かった。

(2)腫瘍細胞が同臓器癌由来で同組織型でも制
癌剤感受性は異なっていた。

(3)腫瘍細胞の制癌剂感受性は継代培養中に, 株化や性格の変化によって高まった。

(4)初代培養腫瘍細胞における感受性試験の成 功率は方法の改善により70\%に達した。また， 成功例での制癌剂感受性は各症例で異なってお ク，制癌剂感受性試験の臨床的意義を示唆した。

\section{謝 辞}

稿を終えるにあたり，終始，懇篤な御指導と 御校閲を戴いた京大胸部研胸部外科, 寺松孝教 授，および天理よろず相談所病院胸部外科，北 野司久部長に深甚の謝意を表します。また，貴 重な癌細胞株の提供を賜わった島根医大病理, 森川茂教授に厚く御礼申し上げます。さらに材 料の提供と絶えざる励ましを戴いた関西医大胸 部外科, 香川輝正教授, 滋賀医大第 2 外科, 岡 田慶夫教授，および京大胸部研胸部外科，伊藤 元彦助教授に禹心より感謝いたします。最後に， 高価な制癌剤を快く提供して戴いた表 1 の各製 薬会社に深謝します。

(本研究の一部は文部省科学研究費, 同がん 特別研究 I〔脇坂班〕, および厚生省がん研究助 成金〔関口班〕の援助によった。)

\section{文 献}

1) Kondo, T. and Ichihashi, H. : GANN, 55 ; 403410, 1964.

2）仁井谷久暢：日本胸部臨床 ; 37 ; 337-344, 1978 .

3）市橋秀仁ほか：日本臨床, 33；1904-1910, 1975.

4) 菊地 浩, 松沢 誠: J. Antibiot. ser. B, 170$174,1955$.

5) Miyamura, S. : Antibiot. \& Chemother. 6; 280$-282,1956$.

6) Kondo, T. et al. : GANN, 57 ; 113-121, 1966.

7) Bickis, I.J. et al. : Cancer, 19 ; 103-113, 1966.

8) Salmon, S. E. et al. : N. Engl. J. Med., 298; 1321-1327, 1978.

9) Ambrose, E. J. et al. : Lancet, 1 ; 24-25, 1962.
10) Berry, R. J. et al. : Br. J. Cancer, 31 ; 218-227, 1975.

11) Wright, J. C. et al. : N. Engl. J. Med., 257 ; 1207-1211, 1957.

12) Limburg, H. und Krahe, M. : Dtsch. Med. Wochenschr., 89 ; 1938-1946, 1964.

13) Hurley, J. D. and Yount, L.T. : Am. J. Surg, $109 ; 39-42,1965$.

14) Dendy, P. P. et al. : Lancet, $2 ; 68-72,1970$.

15) Sykes, J. A. et al. : J. Natl. Cancer Inst., 44 ; 855-864, 1970.

16) Cobb, J.P. et al.:Cancer Res., 21 ; 583-590, 1961.

17) Tanneberger, St. und Bacigalupo, G. : Dtsch. 
17) Gesundheitsw., 22 ; 11-15, 1967.

18) Holmes, H. L. and Little, J. M. : Lancet, 2 ; 985-987, 1974.

19) Pacsa, A. S. : J. Natl. Cancer Inst., 53 ; 13991401, 1974.

20) Freshney, R.I. et al. : Br. J. Cancer, 31 ; 89-99, 1975.

21) Possinger, K. et al. : Klin. Wochenschr., 54 ; 349-355, 1976.

22) Martorelli, B. et al. : Surg. Gynecol. Obstet., $129 ; 1001-1006,1969$.
23) Barranco, S. C. et al. : Cancer Res., 32 ; 27332736, 1972.

24）辻啓次郎ほか：癌と化学療法, 3；74-79, 1976.

25) Limburg, H. : Proc. roy. Soc. Med., 62 ; 361362, 1969.

26) Balconi, G. et al. : Cancer Chemother. Rep., $57 ; 115-124,1973$.

27）下山正徳, 木村禧代二：最新医学, 28 ; 10241040, 1973.

28）長瀬千秋ほか：最新医学，31；1611-1613, 1976.

\section{An experimental study on testing the sensitivity of cultured human lung cancer cells to anti-cancer drugs}

Chiaki Nagase, M. D.

Department of Thoracic Surgery, Tenri Hospital, Tenri

The sensitivity of cultured human lung cancer cells to anti-cancer drugs was tested. For the assay of sensitivity, the inhibition by drugs on the growth of microcolonies of cancer cells in microplates (Falcon, Micro Test II ) was measured. Its inhibition of over ninety per cent was evaluated for the drug to be effective. The results obtained were as follows;

1. The drug sensitivity of cancer cells seemed to correlate with their growth speed.

2. The primarily cultured cancer cells or established cancer cell lines of the same cell type and growth speed showed a different drug sensitivity.

3. The drug sensitivity of cancer cells was elevated when they were established or when they changed their character during the passage.

4. The success rate of the test in primarily cultured cases rose to seventy per cent by the use of discontinuous density gradients that separate cancer cells from other cells or cell debris.

5. The drug sensitivity of primarily cultured cancer cells differed from each other and the clinical usefulness of this test was suggested. 